University of Warwick institutional repository: http://go.warwick.ac.uk/wrap

This paper is made available online in accordance with publisher policies.

Please scroll down to view the document itself. Please refer to the repository record for this item and our policy information available from the repository home page for further information.

To see the final version of this paper please visit the publisher's website. Access to the published version may require a subscription.

Author(s): Giorgio Riello

Article Title: Strategies and boundaries: subcontracting and the London trades in the long eighteenth century

Year of publication: 2008

Link to published version: http://dx.doi.org/10.1093/es/khn004 
This is a pre-copy-editing, author-produced PDF of an article accepted for publication in Enterprise and Society following peer review. The definitive publisher-authenticated version ENTERPRISE AND SOCIETY VOL 9; NUMB 2 (2008) pp. 243-280 Strategies and Boundaries: Subcontracting and the London Trades in the Long Eighteenth Century Riello, G. is available online at: http://dx.doi.org/10.1093/es/khn004

\title{
Strategies and Boundaries: Subcontracting and the London Trades in the Long Eighteenth Century
}

\author{
GIORGIO RIELLO \\ GIORGIO RIELLO is an assistant professor in Global History at the University \\ of Warwick. Contact information: Department of History, University of \\ Warwick, Convetry CV4 7AL, UK. E-mail: g.riello@warwick.ac.uk
}

\begin{abstract}
In the eighteenth century subcontracting was an important way of organising production in sectors producing as different commodities as clocks, coaches, footwear, furniture and scientific instruments. This article argues that subcontracting was not simply a form of cost reduction in labour-intensive and technologically unsophisticated sectors.

Subcontracting could be seen as a way to respond to profound changes in the way commodities were produced, exchanged and consumed in an eighteenth-century metropolis like London. The expansion in size and complexity of the metropolitan market, the appearance of new commodities classified as semi-luxuries and fashion items, and the consequent re-assessment of traditional social structures and norms of production, made subcontracting a tool of organisational flexibility.

In recent years historical and theoretical analyses have furthered our understanding of the organization of production in preindustrial European economies. Since the mid-1980s the concept of "manufacture" and the so-called "alternatives to mass production" have fashioned the historical investigation of what can be synthetically defined as "craft production."1 Twenty years on, the agenda has moved from the consideration of smallscale production in direct opposition to the loose concepts of "mass production" towards more nuanced interpretations. These go back in time into the medieval and early modern periods and survey an increasing range of sectors. 2 The simple opposition between the "modern" factory and "premodern" craft has been thoroughly reassessed by a variety of studies dealing with issues such as preindustrial business practices, the role of networks, and the importance of technical knowledge and social capital.3 They emphasize the plurality of the historical paths of economic development and offer wide-ranging interpretations of preindustrial urban productive systems.4 It is within this new historiographical line of enquiry that research has given particular attention to small-scale trades ranging from the metropolitan luxury production to the making of more mundane commodities such as textiles, clothing, footwear, and furniture.5
\end{abstract}


Drawing from such a bulging literature, this article focuses on the analysis of subcontracting in eighteenth-century London. Its aim is to show how subcontracting was an important way of organizing production in trades producing many different commodities such as clocks, coaches, footwear, furniture, and scientific instruments.6 This article argues that subcontracting was not simply a form of cost reduction in laborintensive, technologically unsophisticated sectors. Subcontracting was to be found in a variety of trades and could be seen as a way to respond to profound changes in the way commodities were produced, exchanged and consumed in the eighteenth-century metropolis. The expansion in size and complexity of the metropolitan market, the appearance of new commodities classified as semiluxuries and fashion items, and the consequent reassessment of traditional social structures and norms of production, made subcontracting a tool of organizational flexibility.

This article starts by considering the historiography and theoretical apparatus currently available for the study of preindustrial subcontracting. It thus considers the emergence and survival of subcontracting in eighteenth-century London by focusing respectively on the expansion and restructuring of consumer markets that accompanied what has been defined as a "consumer revolution." It will then examine changes in the types of commodities produced, sold, and consumed; the role of social institutions such as the guilds, and shared notions of trust and skill among eighteenth-century metropolitan artisans. By way of a conclusion, I will consider the relevance of subcontracting in the context of shifting relationships between producers, consumers, and retailers.

\section{Complexity of Subcontracting: Historiography and Theory}

Small-scale production has been long considered to be the remnant of "traditional" and rather backward productive solutions that characterized only the least innovative parts of the economy. This has been the orthodoxy of political economy since the second half of the nineteenth century. It was argued that small-scale manufacturing was inherently inefficient and that its contribution was a shrinking percentage of a country's GDP, total employment or productivity rates. Already, in the 1960s, however, an innovative historical geographer like Peter Hall argued against such a linear vision of business development and pointed to the kaleidoscopic variety of organizations and enormous economic contribution of several London trades in the second half of the nineteenth century. His analysis indicated that small-scale was not necessarily "simpler" or "backward" and identified a wide range of subcontracting relationships to be found in specific sectors both in the East and West End of the British capital. ${ }^{7}$

The mid-1970s rehabilitation of small-scale industrial production as a dynamic and important part of a country's economy and the 1980s and 1990s theoretical and practical interest in industrial districts have redefined the way in which we think about small businesses, in particular in their reciprocal and continuous interaction through the exchange of information, raw materials, skills, and goods. ${ }^{8}$ These and the abovementioned historical studies on manufactures and alternatives to mass production gave impetus to research on urban subcontracting, especially for the eighteenth century. 
Research by Michael Sonenscher on the Parisian trades, Alain Cottereau on Lyons silk, Cissie Fairchilds on Parisian semiluxuries, John Styles on London goldsmiths, Helen Clifford on London goldsmiths and silversmiths, David Mitchell on London coachmaking, the late Andrew Federer on Westminster coachmaking, and Maxine Berg on provincial British centers of metal toy production, are all central to my present attempt to reassess subcontracting on a more general level. ${ }^{9}$

These studies are important not just for their findings on the dynamics and organizational principles of subcontracting in the eighteenth century. They have all argued against any inevitable path of economic decline for metropolitan manufacturing in the late eighteenth and early nineteenth centuries. In the case of London, studies on subcontracting are in line with the findings of much revisionist scholarship that has "rehabilitated" the metropolis as the major manufacturing center in the country for all of the eighteenth century and through the period classically associated with the industrial revolution. ${ }^{10}$ London's small workshops, sweatshops, and manufactories competed with the high rise of chimneys, factories and prison-like warehouses of the Midlands, North of England, and Lowlands of Scotland. Harvey, Green, and Corfield confidently affirm that during the eighteenth century "London retained a powerful 'clustering' of competitive services and industries that continued to generate positive momentum by means of a system of interlocking feedbacks."11

This essay argues that the emergence of subcontracting was not necessarily the result of cost-reducing measures put in place in order to decrease sale prices and compete with industrial products. A deeper analysis shows how subcontracting emerged in earnest in the late seventeenth century and was connected to innovative changes in the typology and quality of manufactures, new patterns of consumption and changing notions of artisanal life. It thus underlines how the emergence, continuity, perhaps even success of subcontracting in eighteenth-century London was based on the importance of consumption, the relationship between consumers and producers, the types of products exchanged and the implications that these had for the social structure of production.

The line of analysis presented below complements interpretations of subcontracting proposed by the classic "theory of the firm," which mostly focuses on variables endogenous to the firm itself. ${ }^{12}$ Such a theory is articulated through the use of concepts such as economies of scale and scope in an attempt to understand how horizontal and vertical integration and diversification of production yield economic advantages that can only be captured by large and sophisticated firms. Subcontracting can further be analyzed through the conceptual apparatus of transaction-cost economics as developed by Coase and later by Williamson. ${ }^{13}$ The firm exists as a way of internalizing transactions, thus reducing the cost that otherwise an economic agent would have encountered in approaching the market. The cost of exchange is lower within a "coercive institution" (the firm) than in a market where all agents are free. Here, firms are no longer seen only as collective agents, constrained by the rules of classic economic theory (profit maximization and cost minimization), but as flexible organizations that have to deal with problems related to information, opportunism, possibilities, choices, etc. ${ }^{14}$

It should not be a surprise that the internalization of transactions within a firm is more convenient when their frequency is high. In eighteenth-century terms this means that a coachmaker would find it convenient to employ a gilder in his own workshop only when 
a certain proportion of his production is gilded. If only the odd piece was gilded, he had better resort to the market. A second set of reasons why transactions should be internalized refers to the specificity of the investment. An eighteenth-century brewerone of the most extensive types of business organizations at the time-would have in all probability internalized most of its possible transactions due to the very specific nature of the investment. Within this theoretical model, subcontracting can be located at an intermediate level between the recourse to the market (or in business terms the existence of small firms) and the large integrated firm (figure 1).

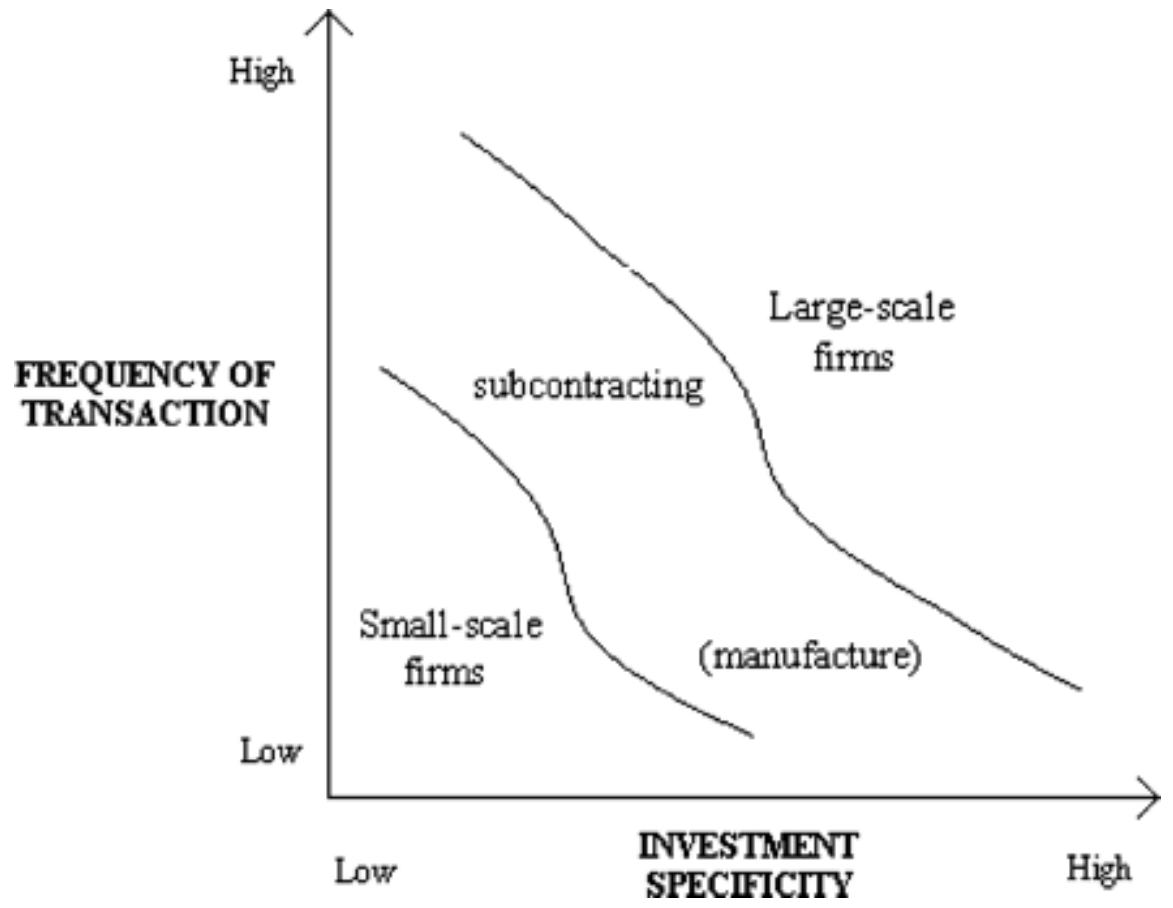

Figure 1 Subcontracting and transaction.

The graph shows that every position between the small-scale and the large-integrated firm could be occupied by forms of subcontracting relationships linked to different degrees of frequency of transaction and transaction-specific investments. I would argue that when the specificity of the investment is high, it is more convenient to adopt a "manufacture" form of production as described by Maxine Berg. This is why subcontracting remained very important in small consumer-goods trades, where the level of investment in fixed capital stayed relatively low, but transaction frequency substantially increased during the eighteenth century. A further point that should be emphasized is that figure 1 should not be interpreted as a diachronic vision of business development, starting from small-scale to arrive at large-scale integrated firms. In this sense, one should be wary of endorsing a widespread idea that — as Dorothy George put it — "in London in the eighteenth century almost every variety of industrial organisation is to be found, corresponding with widely different stages of development". $\underline{15}$ 
Our quest for "rehabilitating" the role of subcontracting as a historical form of production, does not imply that this was either the most important or the most common way of organizing production in the eighteenth century. In quantitative terms, it could easily be argued that small-scale workshops still produced the bulk of the manufactures of the metropolis and that complex, vertically-integrated, large productive plants were more symbolic tokens of progress rather than structural features of the new industrializing economy. History makes life difficult for theory as it provides an enormous range of variations, combinations, and reconfigurations of a murky reality that theory only captures in its distilled essence. The small garret, the large and highly capitalized workshop, and the proto-factory could be found next to each other. However, their existence was not the incarnation of different stages of a universal path of economic development with straightforward oppositions between "modern" and "traditional." They all belonged to the variegated nature of metropolitan manufacturing, based on widely different commodities, consumer needs, skills, and technologies.

The emphasis given to specificity of investment by transaction cost theory has been central to the analysis of subcontracting as a rational response to financial constraints experienced by individual firms. ${ }^{16}$ Among the four key players in transactions (inputs, outputs, producers, and consumers), theories on business structures (and associated costs of transactions) have emphasized the "input-output" line, what I would synthetically call the "line of efficiency" (figure 2). Less has been said about the relationship between subcontracting and the frequency of transaction along the line "producers-consumers."

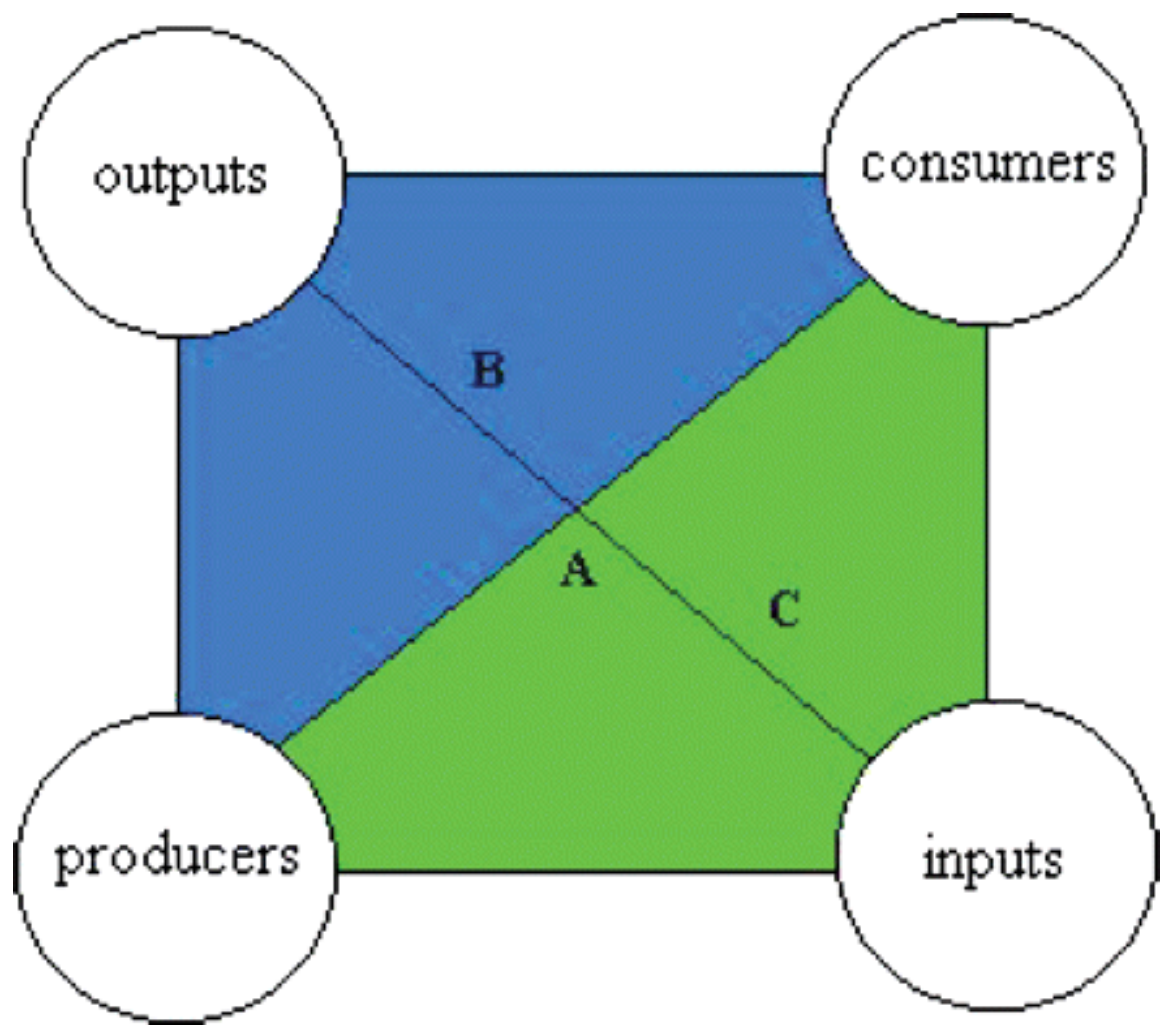

Figure 2 The firm—backward and forward logics. 
To investigate subcontracting, what follows will concentrate on the relationship between producers and consumers along a line that is at the same time a "line of efficacy" (for the firm) and a "line of satisfaction" (for the consumers). This transverse line is determined by the simultaneous working of backward logics of acquisition/internalization of inputs by a firm (as a consumer of inputs) from producers of inputs and forward logics of dispersion/retention of outputs by a firm (as a producer of outputs) to the consumer. The next section will investigate the changes in the relationship between producers and consumers in eighteenth-century London (point A) and their effect on subcontracting. This will be followed by some considerations about "output" (point B), i.e., changes in the commodities produced and exchanged. A final segment will consider the consequences for "inputs" (point C), i.e., the social and cultural context of production and the issue of artisanal skills.

\section{Subcontracting and the Expanding Metropolitan Consumer Market}

Economic historians agree that during the period from the fire of London in 1666 to the 1820s, the British capital experienced an unprecedented expansion. Its population increased from circa 0.5 to 1.5 million, whilst the material landscape of the metropolis extended well beyond the boundaries of the City of London's walls and the Strand, both westwards (the West End), northwards (Bloomsbury and Holborn), eastwards (the East End), and to a lesser extent south of the Thames River.17 Following the nomenclature used above, the "frequency of transactions" in the metropolitan market grew rapidly. London was not just one of the most populous cities in the world but also an expanding market for all sorts of commodities, and in particular for consumer goods.

Such dramatic expansion of the London consumer market did not produce endless specialization. It allowed also the appearance of larger business set-ups catering to a variety of needs. This was the age of what in modern terms we would call "market differentiation" producing not just specific wares, but also capturing collateral markets. For many businesses, subcontracting relieved the core business, allowing investment in other products and services. In the late 1750s, for instance, prominent cabinet makers such as Samuel Norman and the Linnells were able to expand their gilding and carving activities to include the profitable upholstering trade.18 Upholstering could, in turn, be subcontracted to a few of the several businesses active in their neighborhood.

Historians have a difficult task in defining and analyzing a phenomenon such as subcontracting, for it was once ubiquitous and rather fleeting. It was a feature both of industries that required coordination in the production of technologically sophisticated products such as coaches and in relatively simple trades such as shoemaking. Its presence ranged from the lowest trades catering for the urban populace to the manufacture of more fashionable commodities for the court and beau monde.19 Still subcontracting escapes precise definitions as it is difficult to identify and impossible to represent visually. Whilst representations of artisans' workshops, artists' studios, or manufacturers' premises in town and country are not uncommon, subcontracting can hardly be encapsulated in a single visual representation.20 Thus, for instance, Diderot's Encyclopedie, as well as a number of paintings, sketches, and prints, reconstructed the bounded space of individual 
productive units providing a sense of coherence and completeness that was absent in subcontracting.

It is not surprising, therefore, to find the anglophile Sophie von La Roche, minutely describing the workshop of the famous coachmaker John Hachett in Long Acre where she saw "all kinds of workmen necessary for coach and harness-making, and other accessories, working under his [Hatchett's] supervision and producing the loveliest masterpieces of their kind" (figure 3).21 She concluded rather emphatically that she could not think "of any visit more interesting than this one; think of three floors of spacious rooms filled with swarms of busy people whose perfect workmanship is only excelled by still more perfect implements."22 In the 1780s, Sophie von La Roche was perpetuating the myth of the self-sufficient business that provided the visitor with the illusion of constancy in production, both in quantity and quality.23 Fluctuations as well as the flow of semifinished and finished goods were hidden behind this monolithic notion of the workshop. 24

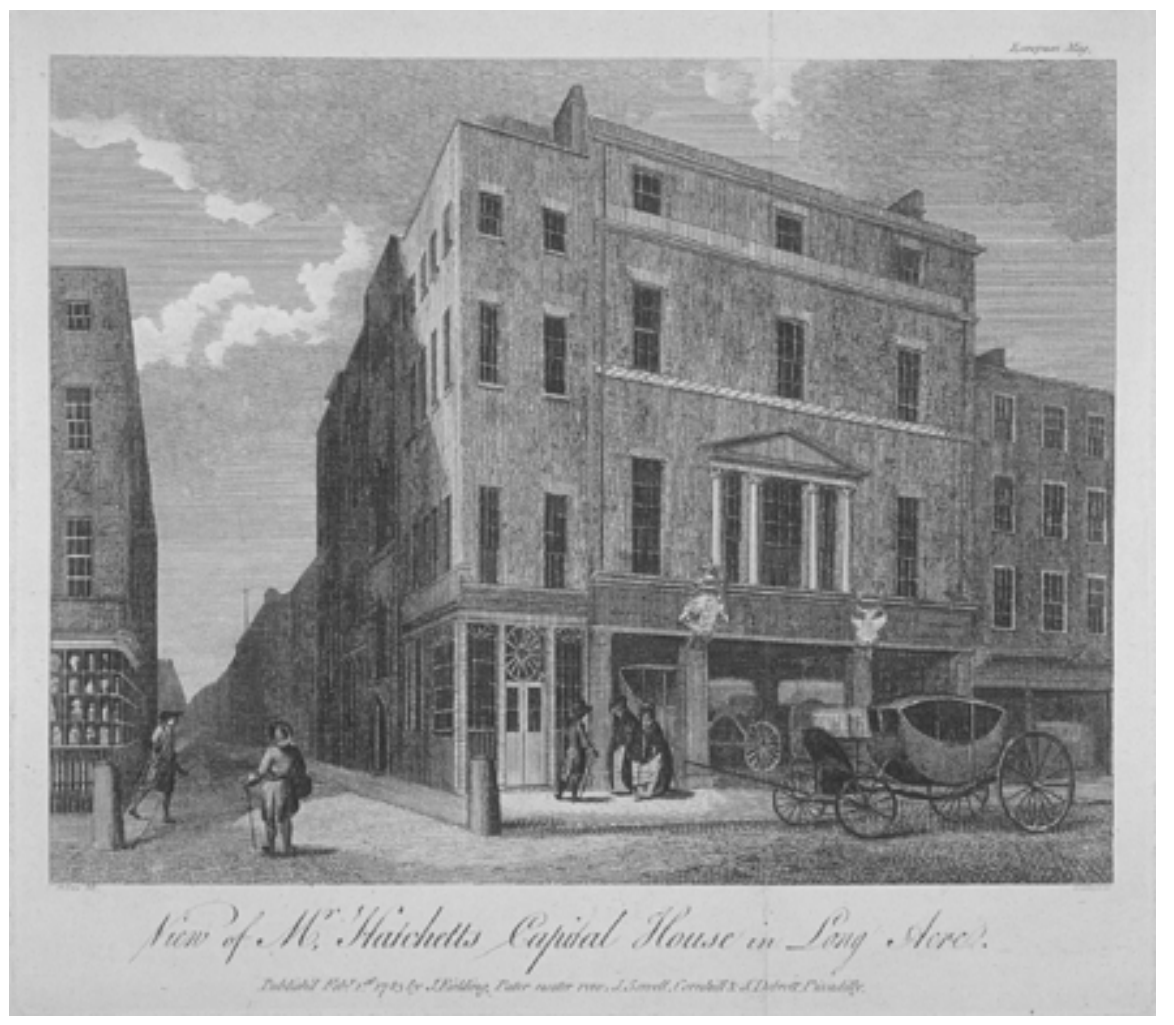

Figure 3 View of John Hatchett's house in Long Acre, by John Walker, Published by J. Fielding, J. Senvell, and J. Debrett, 1783. Guildhall Library Print Room, Pr.W2/LON.

By contrast, historian John Styles claims that eighteenth-century London workshops-the quintessential space of the artisan-were in reality more akin to assembly points than small-scale firms. Increasing demand and a medieval legacy of productive geographies within the metropolis allowed the creation of clusters or poles specialized in the production of specific goods. Subcontracting, if not graphically representable, was visually manifest to anyone walking through the eighteenth century metropolis. Styles 
convincingly argues that many London trades operated within metropolitan industrial districts "with an exceptionally high density of skilled workers in an unprecedented range of trades, linked through criss-crossing networks of subcontracting and piecework".25 Such networks were stretching over the streets of London and into the suburbs, from workshops to back-kitchens, garrets and attics.26 Clock- and watchmaking, for instance, was a rapidly growing trade in eighteenth-century London. The watch was a fairly new commodity and the trade was closely clustered in the Clerkenwell area.27 This was an extreme case of clustering because in this case subcontracting hardly implied any movement of semifinished goods. Many workshops specialized in assembling mechanical components, rather than manufacturing in the traditional sense.

Some subcontracting networks emerging within these structuring geographies of production could be extremely large and complex. As we have seen, Sophie von La Roche marveled at the grandiose appearance of extensive workshops. What she saw was in reality the nerve center of a wider structure that gave employment to dozens, sometimes hundreds, of skilled workmen in the neighboring streets. This was also the case of the anonymous shoemaker who stated in front of a 1738 House of Commons Commission that he employed "162 Persons, from eight to 70 Years of Age," working in every branch of the trade and especially in boot and children's wear.28 Similarly, the Haymarket goldsmith's firm of Parker and Wakelin relied on a network of seventy-five subcontractors in the 1760s.29 Cabinetmaker George Seddon of Aldersgate Street near Gray's Inn Road employed four hundred craftsmen in 1786, a marked increase from 1768 when he employed not more than eighty, suggesting that the expansion of the business was accomplished mainly through subcontracting.30 The average workshop of a London cabinetmaker of the 1760s and 1770s was in fact unlikely to accommodate more than forty or fifty workmen.31

Scholars have argued that the booming demand of the metropolitan market from the second half of the seventeenth century generated the need for long-distance outsourcing involving a shift of part of London's manufacturing capacity to the English provinces. A generally accepted explanation of provincial success in many branches of manufacturing previously exercised by London trades rests on the importance of low wages. In the provinces, metropolitan retailers and entrepreneurs could exploit cheap labor to supply their shops with a wide variety of commodities.32 However, what was initially considered a London expansion increasingly came to be perceived as a threat for the London trades.33 "A Practice hath lately prevailed, of working in the Country, Manufactures for Sale in London, which formerly employed great Numbers of Journeymen in this city"-noticed Corbyn Morris in his 1751 Observations on the past growth and present state of the City of London. He added:

This is visible in the Article of Shoes, in which there are fewer by many hundreds, retained at work, than there were twenty Years ago... and in this Metropolis this Method will probably be followed in many other Branches of Consumption - Especially as the Expense of Carriage from the Country of London, by the Improvement of the Roads becomes easy.34

Morris was not the first commentator to notice such a phenomenon. Already in the 1720 s Defoe in his The Complete English Tradesman had observed how Northampton shoes were commonly worn by many men throughout the country and in the capital, a fact 
again noted by Campbell twenty years later.35 We should, however, be rather careful in implying that this was a "migration" of productive activities from the metropolis to the provinces.36 Historians (especially local historians) have been eager to find points of discontinuity, establishing for instance the rise of Northampton in shoemaking, but also Nottingham in hosiery, Coventry in lace, Birmingham in instrument making and Sheffield in cutlery. London watchmakers started as early as the late seventeenth century to subcontract to the provinces where labor was cheap. Southwest Lancashire and Birmingham made watch components, whilst the London watchmaker merely assembled them and stamped his own name on the final product.37 The very fact that most of such provincial production could only be sold through the metropolitan market makes the dichotomy and direct competition between the two productive spaces (metropolitan vs. provincial) difficult to support.38

The structure of production in some London trades suggests a more sophisticated relationship. Northampton shoes, for instance, found their way to London because of their low cost and an increasing need for large quantities of footwear to supply a continuously expanding market.39 However, before the early nineteenth century the relationship between London and the provinces could be defined more as a form of longdistance subcontracting by London producers, rather than a direct competition between the two areas. Even if the gain were based on the low wages of provincial workmen, it was clear that not everything could be subcontracted. "Vast quantities of inferior kinds of shoes are sold in the metropolis, which are manufactured in Scotland, as well as in Staffordshire, and some other parts of England," observed Mortimer in 1819.40 Yet he also added that "The best men's shoes are manufactured in London, and are commonly known by the hackneyed appellation of town-made."41 At the center of the system was still the metropolis, now able to externalize seasonal or cyclical crises in the retailing market to the provinces through subcontracting.42

The expansion of the metropolitan market provided one of the major stimuli for the creation of subcontracting relationships within and beyond the metropolitan boundaries, in particular for popular products such as garments and footwear. In the case of specialized commodities such as scientific instruments, the development of an English reputation in international markets played a substantial role in the economic growth of places as different as Sheffield, Birmingham, Liverpool, and even Manchester.43 In other industries, such as watch making, the high specialization of labor led to flourishing subcontracting, with individual parts manufactured in Clerkenwell and in Lancashire's Prescot region.44 Similar to shoemaking, provincial scientific instrument makers began to advertise their products only in the nineteenth century, once they no longer felt the necessity to go through the metropolitan market in order to acquire a London signature on their wares.45

Subcontracting was a rather fluid organizational form not only because of its capacity to respond quickly and efficiently to market stimuli, but also because it could be rapidly changed to suit new situations internal to the firm. From "semi-market" relationships with suppliers of generic or specific components and services, subcontracting could lead to the establishment of consolidated links.46 In some cases these links were so strong that businesses amalgamated. We find, for instance, that by 1799 the already mentioned coachmaker Hachett had partnered with two of his subcontractors, becoming "Hatchett, 
Leader, and Vidler".47 In other cases craftsmen integrated private business with subcontracting, switching from one to the other as opportunities presented themselves. James Fayrer spent part of his time working for the instrument maker John Troughton, while remaining a clockmaker and instrument maker in his own right.48 The famous cabinetmaker Samuel Norman subcontracted in the 1750s part of his work to William Long, a Long Acre carver and gilder who also ran his own business.49

Enterprisers thus saw subcontracting as a logical response to the fluctuations of eighteenth-century London's luxury goods market. From the perspective of the London seller, timing was of the essence in keeping consumers happy and shops in full stock. Even in the case of bespoke products, such as the expensive furniture Sir Rowland Winn commissioned from Chippendale in 1767, subcontracting could come up as a risky strategy. Chippendale had to apologize personally for a delivery delay by saying that it was entirely due to "the difficulty there is in having things done according to time, when other workmen are concerned."50 While some borders had been found impossible to match, he explained, another had been "Carved 1 whole month before I co'ld get it Gilt."51 This was the price paid for securing flexibility in times of high or low demand.

Profound seasonal variations affected luxury trades such as gold and silversmithing, coachmaking, printing, and jewelry production. The coming and going of provincial nobility and gentry and the sessions of Parliament created periodic patterns that punctuated production and retailing in the metropolis. If the social season could be precisely forecast, the same could not be said for the climatic variations that affected business. Shoemakers, but also dressmakers and tailors, could find themselves flooded with orders during a bad Autumn or have to wait until well into November to start their winter season. The seasonal nature of many London trades made internalizing production a solution lacking flexibility. Expanding the workshop would have created both the necessity of employing constantly a fixed number of journeymen, as well as a cost in providing space for them. In a city where rents were high, an increase in indoor production would have implied a rise in the fixed cost of rent. Subcontracting allowed proprietors to achieve "economies of space."52

\section{Subcontracting and the Eighteenth-Century Consumer Revolution}

Space was fast becoming a "rare commodity" because shops occupied an increasing portion of the streets of central London.53 Space given to retailing reduced the space for production, mostly carried out in upper floors or cellars by subcontractors.54 Changes in the relationship between production and distribution were supporting a fast expansion in subcontracting, which could be used as a strategy to specialize either in wholesaling or retailing. Campbell, in the late 1740s, was clearly irritated by the emerging class of tradesmen who profited from the "Difference between Buying and Selling."55 Although this was not new in the eighteenth-century metropolis, where shopkeepers had been a prominent and consistent class since the later Middle Ages, the transformation of manufacturing tradesmen into retailers was partially a new phenomenon.

The anonymous author of A General Description of All Trades (1747) thought it to be highly deceptive that in cabinetmaking producers and retailers could hardly be 
distinguished: "for the shop-keeper does not always make every Sort of Goods that he deals in, though he always bears the Title'.56 He explained that there were masters "who keep no Shops, nor Stocks, but principally follow making, and dispose of their Goods as fast as they are finished".57 Under accusation were those tradesmen who coordinated an expanding subcontracting network, while specializing in selling. They profited from the specialization of their activity but attracted the same critical remarks traditionally

reserved to shopkeepers and shopkeeping.58 The separation of production from distribution and the emergence of the "front man" obscured the complexity of sites and people involved in the making of goods.59 Campbell found this "problem" in trade after trade, commenting, for instance, that "of late years the watch-maker, properly so called, scarcely makes any thing belonging to a watch; he only employs the different tradesmen among whom the art is divided, and puts the several parts of the movement together".60

Subcontracting was a consequence of the increasing complexity of the very concept of making. It triggered profound changes in the way goods reached consumers. No longer would the vendor of a commodity also have been the artisan producing it. The variety of goods sold and the complex services performed made the distinction between producer and distributor increasingly unlikely. Pat Kirkham, for instance, has noticed in her study of furniture-making in eighteenth-century London that the emergence of what she defines as "comprehensive manufacturing firms" accompanied sub- contracting.61 Such firms provided an "all-inclusive" service to customers, supplying a variety of items by combining cabinetmaking, upholstering, joining, carving, gilding, etc. Again Sophie von La Roche found one of these firms impressive, eagerly noting in her diary that "the entire story of wood, as used for both inexpensive and costly furniture and method of treating it, can be traced in this establishment."62

No one would doubt that famous cabinetmakers such as Linnell, Seddon or Chippendale ran large establishments that clearly fit within modern notions of large-scale integrated production. However, their "comprehensiveness" relied as much on vertical integration as on "exogenous integration," for these producers often anchored extensive subcontracting systems. With sixty or seventy employees, these establishments were not only several times larger than the average firm operating in cabinet making, but were also central to the life of the entire trade. Gillow, Elliott, and Oakley, established in Oxford Street in 1769, for instance, was a "comprehensive" firm performing both cabinetmaking and upholstering, but at the same time it sold furniture bought from one of the partner's family, the Lancaster Gillows.63 Such firms show how the ostensibly evolutionary path from small to large firms was in reality a mercurial affair, full of contradictions, of shortand long-term economic choices and entrepreneurial opportunism.

The eighteenth century also featured increasing sophistication in terms of products. The material specification of goods was the subject of public debates related to consumption (luxury vs. necessity or moral consumption vs. superfluidities), and involved serious thinking about the complexity of manufactured goods.64 Cabinetmakers, for instance, produced only carcase furniture, but had to leave all finishing stages to other craftsmen such as carvers, gilders, and other decorators.65 The products themselves were becoming too sophisticated to be produced by one hand. Making sophisticated items could be achieved only through increasingly intricate financial and business structures. I will focus here specifically on the quality of the products and will try to identify a relationship 
between the expansion of subcontracting and changes in the types of products manufactured in the British capital.

Quality was a matter of concern in the subcontracting relationships involving long chains of manufacturers, contractors, and final retailers. Subcontracting was an easy and inexpensive way to increase the variety of products for sale, whilst maintaining, at least in part, control over their production. It was a partial insurance that goods would be produced according to standards. Yet standards were difficult to establish, monitor, and maintain. One of the points put forward by historians arguing for the advantages of centralized production over "traditional" decentralized productive methods-normally unfairly equated to proto-industrial rural industries - was the easiness of controlling quality "in the making." Economic theory explains how control over factors of production such as labor, capital, raw materials, and intermediate goods, is greater when managed internally in the firm.66 Historical analysis of labor discipline during the Industrial Revolution has provided a great deal of evidence to corroborate this position.67 Much less, however, is known about the quality of the artifacts produced in factories, workshops, and manufactories.68 According to heated political economy debates during the 1830s and 1840s, industrial methods had decreased rather than increased the quality of goods, and lamentable standards in design generated much theoretical discussion and practical intervention both preceding and following the 1851 Great Exhibition.69

Before these great events that reshaped British economy and society, subcontracting shows us a more subtle picture, involving a reconsideration of the relationship between production, quality, and standardization.70 Surely, the mechanization and technological innovation that framed the new productive world of early nineteenth-century Britain had a foremost effect on the standardization of products. However, this process had already been apparent for decades. In a world in which goods physically took shape through productive processes carried out in disparate places, through exchange and geographical transactions, the elaboration of a shared language and a vocabulary describing product specifications had fully developed long before the application of technology provided the physical capacity to create identical goods in the hundreds, thousands, and even hundred of thousands.71

Shoemaking, for instance, maintained its "preindustrial" structure well into the nineteenth century and encountered real incentives towards centralization of production only after the late 1850s adoption of the sewing machine.72 However, product standardization did precede the mid-nineteenth century. Sizes had been in use since the seventeenth century and became widespread probably by the beginning of the eighteenth. A language of standardization (expressed through sizes) was necessary to satisfy large orders.73 In the case of army supplies, for example, thousands of shoes had to be produced quickly by activating a complex system of subcontractors both in the metropolis and in the provinces, furnishing similar (rarely identical) goods to wholesale contractors.74 In other cases, as underlined by Clive Edwards for the London furniture trade, firms like the Linnell's cabinet workshop relied on suppliers of interchangeable parts used for chairs, drawer fronts, legs, but also screws, bronze hardware, and more complex patterns of inlay and marquetry produced by a variety of subcontractors.75

Brands also appeared well before large firms started to monopolize markets through strategies based on fabricating enormous quantities of goods.76 Brands can be seen as a 
way of "disguising" the complexity of the productive process and the unpleasantries of cellars and garrets, by showing and guaranteeing quality through a process of trust: brands are the paper money of solid-gold quality. Recent research suggests that the "conventional" value of brands and trademarks was widely accepted and used by producers even within the guild system.77 Quality was becoming a "nominal" attribute, difficult to test and impossible to reduce to a specific workman or specific skills. "Labelled" goods such as furniture or shoes guaranteed provenance (figure 4).78 In many cases the retailer became the frontman, whose name appeared on labels ranging from patent medicines to ketchup sauces.79 Tradecards and headbills reinforced the public image of shops that increasingly became the favorite contact point for consumers of all ranks in the metropolis. 80

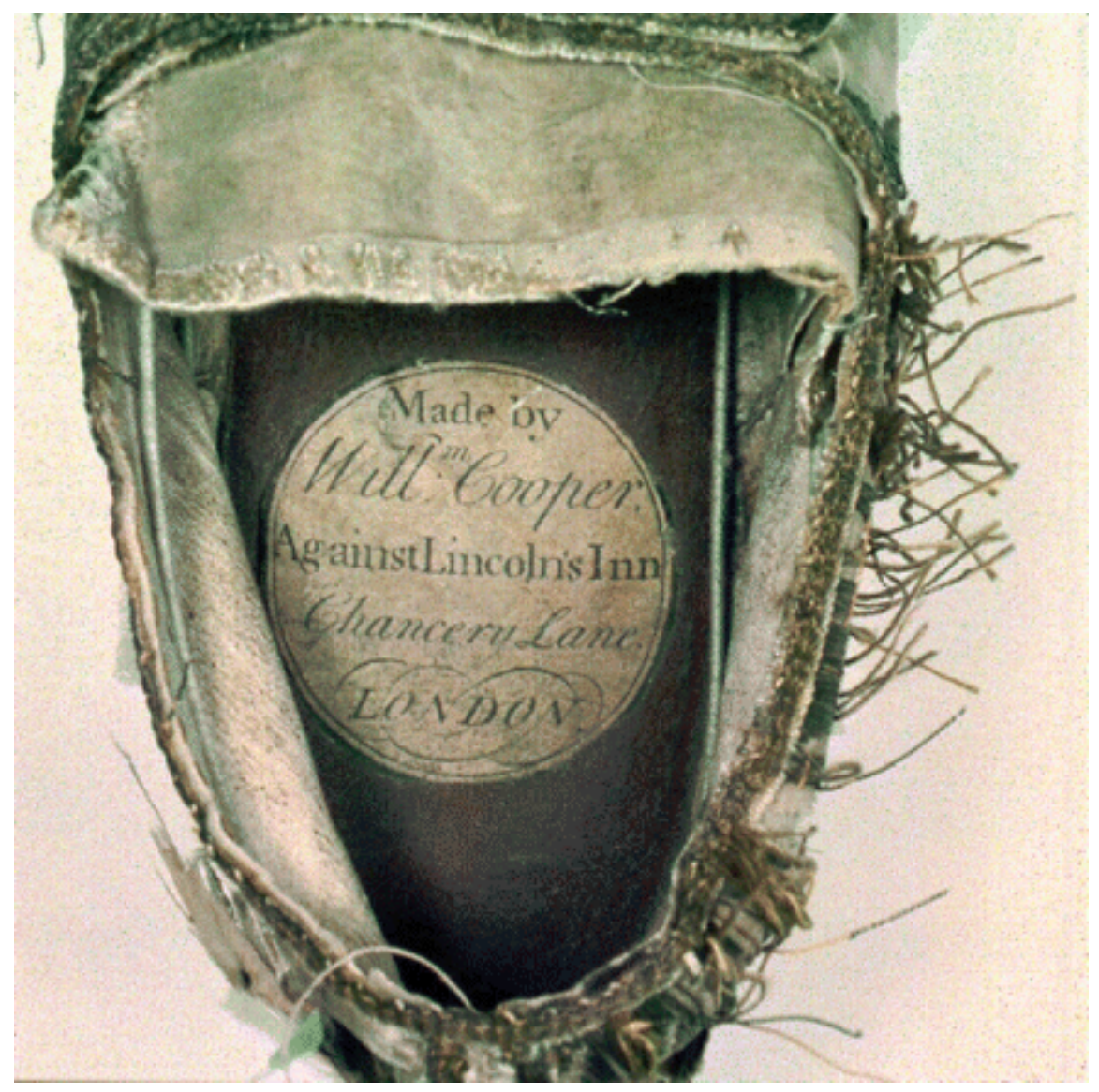

Figure 4 Shoemaker's label: "Made by William Cooper, Chancery Lane, London". Royal Ontario Museum, Toronto 921.2.19. Photo Brian Boyle. Reproduced courtesy of the Veronika Gervers Research Fellowship.

Subcontracting presented clear advantages in the so-called luxury trades producing fashionable objects. Here quality was important but the type of products manufactured could hardly be defined as unique. Many items belonged instead to the realm of the demiluxe and were often subject to seasonal fashion changes. In these trades, a key problem was not just to acquire the necessary skilled labor, but to employ artisans who specialized 
in specific tasks, often working in their own premises. For example, porcelain produced in the capital was often sent to be decorated in studios and painting shops elsewhere.81

A question remains, however, as to whether subcontracting was suited only to the production of custom-made commodities. The case of shoemaking, the invention of sizes, the appearance of brands and the complexity of coachmaking-all remind us that subcontracting was operating with commodities that did not fully fit within the notion of individually crafted artifacts. These "unique" pieces represent what is here defined as "luxury" craft production.82 In this domain, quality, individuality, craftsmanship, and artistic attributes are important not only in defining the final product, but also in shaping production, normally carried out in small workshops. At the opposite end the spectrum, "mass" industrial production is characterized by the making of standardized identical items normally in large quantities through the use of complex technologies (table 1).83 This typology has in "luxury" and "mass" two extremes that are not dissimilar from the classic opposition between ancien régime workshops and modern industrial systems of production.

Table 1 Types of Products and Related Systems of Production

\begin{tabular}{|c|c|c|c|c|c|}
\hline Product & Attributes & Production & Technologies & $\begin{array}{l}\text { Main Competitive } \\
\text { Advantage }\end{array}$ & $\begin{array}{l}\text { Relation } \\
\text { with } \\
\text { Customers }\end{array}$ \\
\hline Unique & Luxury & Craft & $\begin{array}{l}\text { High } \\
\text { skills/high or } \\
\text { low } \\
\text { technological } \\
\text { investment }\end{array}$ & Quality (highest) & Bespoke \\
\hline $\begin{array}{l}\text { Small } \\
\text { quantities } \\
\text { with } \\
\text { variations }\end{array}$ & Fashionable & Populuxe & $\begin{array}{l}\text { Medium } \\
\text { skills/some } \\
\text { technological } \\
\text { investment }\end{array}$ & Appeal/innovation & $\begin{array}{l}\text { Some } \\
\text { bespoke } \\
\text { and } \\
\text { increasingly } \\
\text { (market- } \\
\text { oriented) } \\
\text { ready-made }\end{array}$ \\
\hline $\begin{array}{l}\text { Large } \\
\text { quantities } \\
\text { with (some) } \\
\text { variations }\end{array}$ & Undifferentiated & Serial & $\begin{array}{l}\text { Low } \\
\text { skills/low } \\
\text { technological } \\
\text { investment }\end{array}$ & Convenience & $\begin{array}{l}\text { Totally } \\
\text { (production } \\
\text { oriented) } \\
\text { ready-made }\end{array}$ \\
\hline Standardized & Mass & Industrial & $\begin{array}{l}\text { Low } \\
\text { sills/high }\end{array}$ & Price (lowest) & Mass \\
\hline
\end{tabular}


Fundamentally there is no historical evidence that "mass" production is the most efficient way of producing goods, whatever the economic context or products manufactured. The field of present-day fashion, for instance, shows the coexistence of couture next to massproduced clothing, with profound and intricate historical links between the two. In between "luxury" and "mass," a vast array of products fit—admittedly with difficulty— into two broad categories of "fashionable" and "undifferentiated." By "undifferentiated" I mean serial products manufactured in large qualities (sometimes with minor variations) through the use of relatively simple technologies. These products are sought after by consumers for their "convenience."84 Finally, but central to my argument is the category of "fashionable" products manufactured in small quantities with variants and modifications over time. These are products such as fans, snuff boxes, porcelain and tea cups, watches, and umbrellas described by Cissie Fairchilds for the eighteenth-century Parisian and by Maxine Berg for the London and other European metropolitan markets.85 Bought for their appeal and innovation, these items entailed a certain degree of skill, but not necessarily extensive financial investment in fixed capital for their manufacture. Most such objects could be purchased ready-made, although they could be customized (as in the case of expensive coaches or much cheaper sets of china plates).86 Their main difference compared to "undifferentiated" products is that they were marketoriented ready-made products, conscious of the variations and vagaries of fashion, conspicuous consumption, and consumer whimsy.87

These "populuxe" products were hardly the reification of consumers' requirements. Issues with the quality (perceived or real) of products remained and actually intensified in the decades following Campbell's book, leading to a constant rethinking of products by customers and producers in their dynamic relationship with structures of production. The already mentioned separation of production and retailing caused an enormous growth in the sale of ready-made items. While at the beginning of the eighteenth century readymade was still considered an option for the lower classes or for the purchase of utilitarian items, by 1800 the very concept of ready-made had been transformed. It stood now for variety, choice, and immediate purchase in shops, warehouses, and small and large retailing premises in which no trace of production could be seen.88 In the early eighteenth century, shoemakers advertised the quality of their bespoke production; a century later trade cards talked about stocks of thousand of pairs of shoes, a retailing world characterised by historians as made of "fast buying" and "fast selling."89

Semiluxuries, copies, imitations, and niceties formed a vast and heterogeneous category of goods. They were different from unique pieces and entered the consumer market in unprecedented numbers. For retailers, subcontracting - as a way of acquiring part of the stock for sale - was a strategy implemented in different markets. On the one hand, customers were increasingly sophisticated and asked for items involving difficult production. On the other, a market existed for inexpensive items alongside that for specialized products. It is not surprising that Chippendale had to supplement his stock by 
buying ready-made furniture, especially Boulle-work and chair-frames in French style. This was what refined customers would expect to be able to buy in Chippendale's St Martin's Lane shop. However, they would also expect the famous maker to furnish their house from top to bottom, including kitchens and servants' quarters. This latter furniture Chippendale had to subcontract, some of which came ready-made and some made-tomeasure.90

The multinodal market that a supposedly elite cabinetmaker such as Chippendale targeted exemplifies the complex relationship between production, the quality of the product, and the variety of skills that an "artisan-entrepreneur" coordinating subcontracting networks had to mobilize. This necessity has in turn profound consequences for established ideas on craftsmanship and intellectual and artistic authorship commonly adopted by art historians, economic historians, and historians of the decorative arts.91 The fact that a large number of pieces of Chippendale's "production" were not executed under his own direct supervision or within his workshop suggests the need to revise our understanding of individual attribution of artistic production.92 This issue highlights the wider consequences of subcontracting in the sociocultural context of manufacturing and on the meaning of craftsmanship in eighteenth century London.

\section{Subcontracting and its Notions of Manufacturing}

As Helen Clifford has established for the production of plated and other alloy silverware, consumers were hesitant in judging products that did not fit with established notions of value and craftsmanship, key attributes to manufacturing before the age of machines.93 If tradesmen's engagement in retailing activities raised more than one eyebrow, concern arose also about the parameters of craftsmanship and about what apprentices were supposed to learn in order, one day, to carry out a profitable business on their own account. Thus a foreign journeyman who arrived in London in 1788 to learn the rather exclusive trade of instrument making, wrote home that few skills could be learned in famous makers' workrooms:

I am convinced that it was not with Nairne and Blunt, Adams, Dollonds or their peers from whom I would have learnt anything, as their most prestigious instruments are manufactured all round the city, and what men they employ in their houses are either simply put to repairing instruments, or making some small adjustments.94

This decentralized situation posed a series of challenges to the once straightforward relationship between products and production. Campbell, for instance, was unhappy to find that:

after the watchmaker has got home all the... parts of which it [a watch] consists, he gives the whole to the finisher, having first had the brass wheels gilded by the gilder, and adjusts it to the proper time. The watchmaker puts his name on the plate and is esteemed the maker, though he has not made in his shop the smallest wheel belonging to it.95

Campbell perceived that subcontracting had changed the very notion of skill. Though he did not fabricate, the artisan/assembler had at least to be able to monitor the final result: "He must be a judge of the goodness of the work at first sight, and put his name to nothing but what will stand the severest trial, for the price of the watch depends upon the reputation of the maker only."96 
These quotations help convey the profound anxiety and resentment towards eighteenthcentury changes that affected not just manufacturing per se, but also the labor, social, and cultural roles of the workman. Subcontracting had brought about changes in shared notions of artisanal skills and profound modifications of formal and informal institutions that for centuries had supported and underpinned metropolitan manufacturing.97 In the case of the 1774 caricature "Deny it if you can, NINE TAYLORS makes a MAN" (figure 5), division of labor was represented as the dismembering of the body and a gross violation of nature: the tailors are no longer skilled workmen but are reduced to savagery and unruliness. This satirical print can be read as a defense of traditional ideas of making and of a certain anxiety about the nature of the very commodities produced through new productive processes. From an entrepreneurial point of view, however, subcontracting could be seen as a flexible means to provide access to particular skills or to products that only with difficulty could be produced within the workshop.98

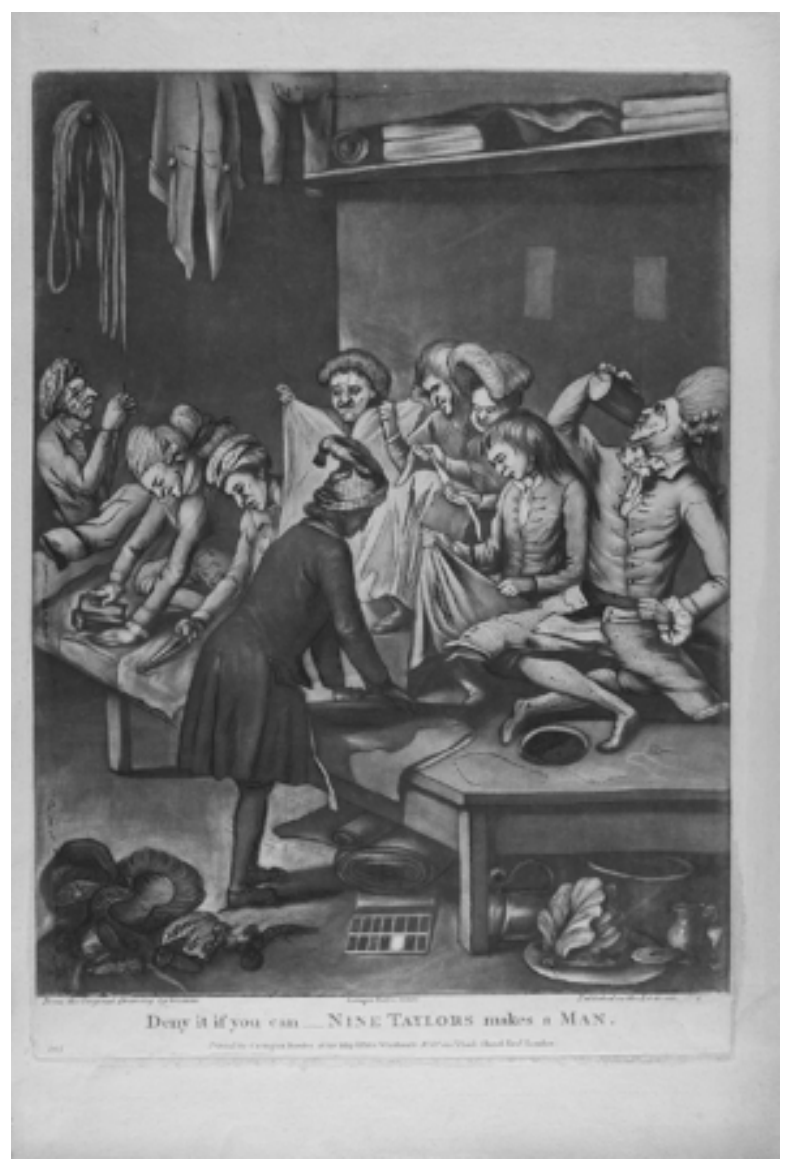

Figure 5 'Deny it if you can, NINE TAYLORS makes a MAN', Satirical caricature, London, Printed for Carington Bowles, Map \& Printseller, 24 May 1774. 32 x 25 cm. Yale Center for British Art, B1970.3.774.

Entrepreneurs viewed subcontracting not just as a cost-saving way to increase or decrease production according to need, but also as a means to shift the very boundaries of the firm, selectively accessing specific skills, knowledge, know-how, and product specializations.99 The scientist Bernouilli remarked during his visit to London in 1769 
that the famous instrument maker Dollond could not cope with the sheer volume of orders. He had to rely therefore on subcontractors, turning to a close relative first:

To maintain his reputation, he [Dollond] has the mountings, the division etc., made by his brother-in-law Ramsden who passes for one of the best craftsmen in London of this type. This Ramsden also sells telescopes with a good reputation. Maybe brothers-in-laws assist one another; whatever the situation, Ramsden's telescope mounting gave me much pleasure. 100

In other cases, the need to engage skills external to the firm extended well beyond close manual dexterity, family links or even mechanical proficiency. In trades such as instrument making, subcontracting combined scientific knowledge and practical craftsmanship. The trade was famous not only for its large network of producers, but also for the necessity to integrate experts' knowledge into the final products. The scientific instrument maker therefore relied upon practicing scientists who provided not only ideas, but also personal commissions and other scientists' patronage. Similarly, Adam Smith suggested that more than 3000 artisans in a variety of London trades were dependent upon the work commissioned by the Adam brothers, the most successful architects of the time.101 Forms of "cultural subcontracting" complemented and supported networks of "manufacturing subcontracting."102 Chippendale heavily relied on the skills of "experts" that he needed for making specific items. He thus had to subcontract most of his upholstering work that entailed the dyeing of fabric, as well as glass for bookcases and horologic components for clocks.103

Subcontracting provided several benefits also from a wider social point of view. As Honeyman and Goodman notice, subcontracting acted as a "wage substitute" strategy in which "[s]ocial rewards, status, esteem, independence of supervision, dignified treatment, and mobility were part and parcel of this world".104 It allowed craftsmen, effectively in a dependent position, to portray themselves as independent businessmen rather than as simple workmen. Although an innovative way of organizing production, subcontracting created continuity through the use of the language and concepts that for centuries had dominated manufacturing in London. Many workmen employed by large subcontractors defined themselves as having been brought up to the "arts and mysteries" of a trade. These assertions hid their dependent position behind a traditional language of trade, as recently underlined by sociohistorical investigations of how the language of occupation shapes identity.105 A sense of familial or social identity constructed through subcontracting helped in consolidating bonds in a shifting business environment.

The need for confirmation of established categories of occupational self-definition arose at a time of profound changes in pre-industrial urban manufacturing. By the late seventeenth century, guilds had become ineffective in controlling their respective trades. Their guidance and assistance of craft matters was partial and discontinuous.106 Freedom to enter new markets was increasingly left to entrepreneurs and their capital investments, rather than expecting compliance to guild rules. When not completely ignored, London guilds dealt with subcontracting by referring to traditional institutional rules and by protecting their respective members, even though outsourcing and subcontracting clearly conflicted with the corporative ethos. Guilds were keen to interfere only in those cases that placed at risk the rights and well being of their own members.107 
The coachmaking business, for instance, relied heavily on subcontracting.108 The cost of the final product, the high skills required, and the bespoke nature of the trade made the division of labor rather straightforward. The entrepreneurial coach maker directed from his often substantial premises a large number of out-workers, who provided a wide range of goods and services. The Coach Makers' Company, accustomed to such a state of things, assented — although not formally — to its members directing much larger undertakings than they were willing to admit. However, when in 1754 a certain John Miles, a wheelwright living in Camomile Street, St. Mary Axe, decided to expand his business to include coach and harness making, the Company acted promptly. This was not a simple case of unlawfully exercising a trade without proper apprenticeship, one of the frequent manifestations of the blurring of the boundaries among trades. The Coach Makers' Company complained, of course, that Miles had "any the least knowledge in the trade of coach making," but its real concern was that Miles had played the game, without being a member of the group, reversing the classic relationship between entrepreneur and contractor:

he undertook to do all sorts of business for his own Lucre and Benefit, and employed some journeymen coach makers and wheelers and Mr Miles was a wheeler and was one who was employed as well as by Gentlemen to make their wheels as also by Coach makers, he had frequent opportunities of recommending himself to Jobb.109

Miles, as a wheelwright had not the right to manage a business that hired coach makers, even if the trade of coach making was probably not carried out at his premises.

At a first glance, this account of Miles may appear insignificant. But it shows how trust was central to the working of the entire system.110 The cost of transactions decreases if the environment in which they take place is governed by ethical behavior, respect of contracts, and norms of fair play. The Coach Makers' Company was particularly irritated by the fact that Miles had all the opportunities to earn a living from his own activity ("he had frequent opportunities of recommending himself to Jobb"), but exploited his access to customers, suppliers, and knowledge to his own advantage.

Another classic problem of subcontracting, outsourcing, and putting out was the embezzlement of the raw materials or intermediate goods given out.111 These are classic manifestations of what economists call "free riding," that is to say acquiring an advantage simply because the other party has neither control nor a general monitoring capacity. Trust and the repetition of the "game" (i.e., the continuity of the relationship between employer and subcontractor) should ensure the minimization of free riding. A case in point is the watchmaker William Vandamme, whose house was robbed in July 1774. Vandamme, a skilled immigrant, was living in Hog-lane, Crown Street in Soho, where he shared his house with two lodgers-a watch finisher and another workman operating in the same trade. Vandamme regularly bought watch movements and the three produced timepieces to sell to watchmakers in the Covent Garden area. Their activity must have been well known in the area for a fellow watch finisher, a certain John Mince, was accused of robbing Vandamme and then trying to sell the movements to watchmaker James Sedgwick.112

This case underlines the importance of trust in the construction and implementation of subcontracting: trust among producers, between masters and subcontractors and between 
producers and retailers. Vandamme's case was easily classified as theft by the Old Bailey. Its proceedings show that Vandamme gave the lodgers free access to the movements and that he entrusted them with the key of his bureau. Sedgwick, who portrayed himself as an unconscious receiver of stolen goods, admitted that he had questioned Mince about their provenance. Mr Ryland, maker of the movements, could identify the wares, even if the letter "R" (standing for "Ryland") was no longer there: "they are sunk frames; we make none of that sort for any person but Mr Vandamme."113 The cohesiveness of the entire productive network thus emerges as one of the most important factors allowing the system to work. This type of productive network did not rely on anonymous transactions. Face-to-face daily exchanges remained important in securing trust, guaranteeing delivery, and maintaining quality.

\section{Conclusion: History and Subcontracting}

This article has shown how subcontracting encompassed a larger category of organizations of production in eighteenth-century London than would be expected from simple efforts to reduce manufacturing costs. Prices and costs of production were a part of, but not central to, the existence and prosperity of subcontracting. By focusing on consumer goods, I have argued that subcontracting was an innovative response to the profound market changes that social, cultural, and economic historians in recent years have described as a "consumer revolution." Subcontracting was particularly suitable for the organization of production of fashionable wares, semiluxury items, and the latest fashions that consumers increasingly expected to be ready to be bought up in Europe's largest consumer market.

Subcontracting was part cause, part effect of changes in the way these commodities looked, the way in which they were distributed, and the way in which consumers approached them. The emergence of shops as separate spaces from productive workshops, the increase in "branded" products and the creation of a language of standardization supported not just emergent mass production but also more complex forms of manufacturing like subcontracting. All of this happened within a specific cultural and social context or "culture of production" still based on face-to-face relationships between the parties involved in the productive process, an environment in which trust and social surveillance ensured the respect of unwritten norms, thus creating the conditions for the survival of subcontracting as a form of urban manufacturing well into the industrial age.

\section{Footnotes}

I would like to thank Maxine Berg, Richard Butler, Helen Clifford, Negley Harte, Liliane Hilaire-Pérez, David Mitchell, Peter McNeil, Patrick O’Brien, Anna Spadavecchia, John Styles, and the anonymous referees for their help and feedback. Previous versions of this paper were presented at the seminar in History of Design and Material Culture, Victoria and Albert Museum, November 2004 and the Business History Unit seminar, London School of Economics, April 2006.

1 Maxine Berg, Pat Hudson, and Michael Sonenscher, eds., Manufacture; Piore and Sabel, Second Industrial Divide; Sabel and Zeitlin, "Historical Alternatives;" Berg, ed., Market; idem, Age of Manufactures. 
2 Farr, "On the Shop Floor." See also Sabel and Zeitlin, eds., World of Possibilities.

3 See for instance: Berg, "Small Producer Capitalism;" Iliffe, "Material Doubts;" Reynard, "Manufacturing Strategies;" Clifford, "Concepts of Invention;" Young, "Manufacturing;" Smith, "Swiss Connection."

4 Hohenberg, "Urban Manufactures," 159-63; Richards, "Margins," 213; Harvey, Green, and Corfield, "Continuity, Change, and Specialization," 470-71.

5 For an overview on London see: Daunton, "Industry in London." Individual London trades such as furniture and shoemaking are analyzed in Kirkham, London Furniture Trade and Riello, "La Chaussure à la Mode," idem, Foot in the Past. For other European cities and areas see: Kaplan, "Luxury Guilds," 273-75; Sonenscher, Hatters; idem, Work and Wages; Fox and Turner, eds., Luxury Trades; Decelauer, "Entrepreneurs;" idem, "Between Medieval Continuities."

6 The analysis will limit itself to subcontracting in the production of specific artifacts (in particular consumer goods) and will focus mainly on London, although links between the metropolitan tradesmen and provincial subcontractors will be highlighted. In the impossibility of examining a wide-ranging sample of sectors, this paper concentrates on specific trades: clockmakers, coach makers, furniture producers, scientific instrument makers, shoemakers, and silversmiths provide a cross section of consumer goods trades in the long eighteenth century. I here distinguish between "subcontracting" and "puttingout systems." The latter has a rather specific connotation in terms of wider theories (i.e., proto-industrialization and industrious revolution). The former maintains a "business" nature that is not evident in putting out (this is why subcontracting rarely refers to the household, for instance). Subcontracting is very much urban, putting-out is not. Puttingout has been deployed mostly for textile production. The author is however aware that in some cases the two systems overlapped.

7 Hall, Industries in London. See also idem, "East London Footwear Industry."

8 On the importance of small businesses see: Schumacher, Small is Beautiful. The literature on industrial districts is enormous in the case of Italy and has in more recent years become a topic of analysis also for Britain. Key texts are: Popp, Business Structure and Wilson and Popp, eds., Industrial Clusters, especially introduction.

9 Federer, "Payment;" Sonenscher, Work and Wages; Fairchilds, "Production and Marketing;" Cottereau, "Fate of Collective Manufactures;" Styles, "Goldsmiths;" Clifford, "King's Arms and Feathers;" idem, Silver in London, Ch. 5; Mitchell, "Coachbuilding;" Berg, Luxury and Pleasure, pp. 168-69.

10 See in particular the excellent volumes by Schwarz, London and Green, From Artisan to Paupers. See also Godley, "Development;" Green, "Nineteenth-Century Metropolitan Economy;" Johnson, "Economic Development;" Michie, "London and the Process of Economic Growth;" Barnett, London; Godley, Jewish Immigrant Entrepreneurship; Ball and Sunderland, Economic History of London; Loftus and Riello, "Historical Fashion."

11 Harvey, Green and Corfield, "Continuity, Change, and Specialization," 472.

12 For an overview of recent literature on the "evolution of modern business," see: Casson and Rose, "Institutions." 
13 Coase, "Nature of the Firm;" Williamson, "Transaction Cost Economics;" idem, Economic Institutions of Capitalism. See also Langlois, "Chandler."

14 For a brief summary see Boyce and Ville, Development of Modern Business, 16-18. 15 George, London Life, 164. The italics are mine.

16 Federer, "Payment."

17 Sutton, "Metropolitan Artisans," 27. See also the classic article on the London economy by Wrigley, "Simple Example," pp. 44-68 and the collected papers by Fisher, London.

18 Kirkham, "Samuel Norman," 502.

19 For the top of the market see Baker, "Roubiliac."

20 Fox, "Images of Artists," 357-59.

21 La Roche, Sophie in London, 158-9.

22 idem On Hatchett see also Wackernagel, "Carlton House Mews."

23 Hilaire-Pérez, and Thébaud-Sorger, "Techniques." See also Hilaire-Pérez, "Boutiques d'Inventeurs" on the experience of visiting an eighteenth-century workshop.

24 Freundel, "Production," 51.

25 Styles, "Goldsmiths," 114. Farr argues that this was true also for the early modern period. Farr, "On the Shop Floor," 26, 39-42.

26 Linebaugh, London Hanged, 226.

27 Similarly the coachmaking trade was clustered since the end of the seventeenth century in the Long Acre area. However, other trades that relied on subcontracting such as shoemakers and hatters were scattered in the West End and the City. Spate, "Geographical Aspects," 425.

28 British Parliamentary Papers, Common's Journal, 23 (3 May 1738), 178.

29 Snodin and Styles, Design and the Decorative Arts, 290.

30 Wackernagel, "Carlton House Mews," 55.

31 Hayward and Kirkham, William and John Linnell, 45.

32 Trinder, "Industrialising Towns."

33 See for instance the article by Clifford, "Concepts of Invention."

34 Morris, Observations, p. 20.

35 Defoe, Complete English Tradesman, i, 243.

36 DuPlessis, Transitions to Capitalism, 113.

37 Earle, Making of the English Middle Class, 23.

38 Schwarz, London in the Age of Industrialisation, 39; Berg, Luxury and Pleasure, 16869; Riello, Foot in the Past, 222-33. 
39 Hatley and Rajczonek, "Shoemakers in Northamptonshire," 3.

40 Mortimer, General Commercial Dictionary, 160.

41 idem William Collier, a shoe manufacturer in Stafford, reported to an 1812

Parliamentary commission that "half of the shoes they sell here (in London) as bespoke shoes, are the manufactures of Stafford and Northamptonshire." British Parliamentary Papers, Select Committee on Petitions Relating to Duty on Leather, 4, no. 593 (1812-13), 647.

42 The argument is more extensively analyzed in Riello, Foot in the Past, ch. 8.

43 Morrison, "Role of Subcontractors," 15.

44 Landes, Revolution in Time, passim.

45 Morrison, "Role of Subcontractors," 14.

46 Earle, Making of the English Middle Class, 27-8.

47 Freundel, "Production," 42-3.

48 McConnell, "From Craft Workshop to Big Business," 45.

49 Kirkham, "Samuel Norman," 502.

50 Cit. in Gilbert, Life and Work, 33.

51 idem

52 Federer, "Payment," 11-12.

53 Walsh, "Shop Design." For a wider study see Cox, Complete Tradesman.

54 Styles, "Goldsmiths," 115.

55 Campbell, London Tradesman, 127.

56 General Description of all Trades, 49.

57 idem, 50.

58 Cox, "Beggary of the Nation."

59 See in particular the brilliant exercise by Clifford who explains the complexity of Parker and Wakelin's silversmith production by tracing all the subcontractors employed by the firm in the production of a dinner service commissioned by Earl Harcourt to the firm in 1768. Clifford, Silver in London, pp. 65-6.

60 Campbell, London Tradesman, 250.

61 Kirkham, London Furniture, 61.

62 Von La Roche, Sophie in London, 175.

63 Kirkham, London Furniture, 63 and 72.

64 See in particular Berg, "New Commodities;" idem, "From Imitation to Invention."

65 Kirkham, London Furniture, 58.

66 Jones, "Organization of Work;" Szostak, "Organisation of Work." 
67 See for instance McKendrick, "Josiah Wedgwood;" Pollard, "Factory Discipline;" Thompson, "Time;" Clark, "Factory."

68 Ball and Sunderland, Economic History of London, 297.

69 See in particular Kusamitsu, "British Industrialization;" Kriegel, "Culture and the Сopy."

70 Snodin and Styles, Design and the Decorative Arts, 290.

71 For a far more incisive analysis than the present one see Styles, "Manufacturing," 333-34.

72 Swann, "Mass Production."

73 Styles, "Product Innovation."

74 Smith, "Army Clothing Contractors."

75 Edwards, Eighteenth-Century Furniture, 25 and 110.

76 On Branding see Styles, "Manufacturing," 541-42.

77 On the use of conventional agreements on quality see Alessandro (ed.), Qualité des produits, especially the introduction, pp. 5-22. For an applied case, see the article by de Munch, "Qualité du corporativisme."

78 Bowett, and Lindey, "Labelled Furniture."

79 Riello, "Taste of Italy;" Wallis, "Consumption."

80 Berg and Clifford, "Commerce and the Commodity;" Clifford, "Nation of Shopkeepers;" Scott, "Waddesdon Manor Trade Cards."

81 Fox, "Images of Artists and Craftsmen," 360.

82 On this topic see Scranton, Endless Novelty, 10.

83 This typology of production has been elaborated and adapted from Scranton's formulation concerning late nineteenth-century American manufacturing. idem

84 If one would want to force the argument, "serial" production could be seen as the outcome of manufactories and proto-factories, although it could well be applied to all kinds of products and productions before the 1890s. An example of the difficult to cell, but important distinction between what I define "mass" and "serial" production can be found in an incisive article by Davies, "British Watchmaking."

85 Fairchilds, "Production and Marketing," in particular p. 228 and note 6; Berg, "French Fancy." See also Lewis, "Producers;" Coquery, "The Language of Success;" Berg, Luxury and Pleasure, 169.

86 Again the parallel to the present-day fashion market can be of use. In between "couture" and "mass," the categories of "prêt-à-porter" and "fast fashion" are commonly used to identify for the former the production of serial products and for the latter of "populuxe" products. One thing to notice is that "fast fashion" is actually cheaper than "prêt-à-porter." 
87 On the relationship between products and the so-called eighteenth-century consumer revolution see: Styles, "Manufacturing;" Reynard, "Manufacturing Quality;" Styles, "Product Innovation,"

88 Walsh, "Shop Design." On ready-made clothing see: Ginsburg, "Tailoring and Dressmaking Trades," 67; Lemire, "Developing Consumerism;" idem, Dress, Culture and Commerce; Deceulaer, "Entrepreneurs in the Guilds." See also Chapman, "Innovating Entrepreneurs;" Sharpe, "Cheapness and Economy;" Zakim, Ready-Made Democracy; and Chapman, "Revolution."

89 Riello, Foot in the Past, 94-105.

90 Gilbert, Life and Work, 35.

91 Baker, "Roubiliac," 90; Clifford, "Making Luxuries," 18; idem, Silver in London, 623.

92 Gilbert, Life and Work, 33; Snodin and Styles, Design and the Decorative Arts, 292.

93 Clifford, "Innovation or Emulation?;" idem, "Concepts of Invention."

94 Cit. in McConnell, "From Craft Workshop to Big Business," 38.

95 Campbell, London tradesman, 251.

96 idem

97 See Farr, "Cultural Analysis," 63-9. See also Berlin, "Broken all in Pieces."

98 Federer, "Payment," 11. He considered in particular the coachmaking trade in Westminster. See also Wackernagel, "Carlton House Mews."

99 On this point see the excellent piece by Cottereau, "Fate of Collective Manufactures."

100 Bernouilli, Letttres Aestronomiques, 69. Cit. in McConnell, "From Craft Workshop to Big Business," 44.

101 Clifford, Silver in London, 62.

102 See for instance Guerrini, "Anatomists."

103 Gilbert, Life and Work, 34.

104 Honeyman and Goodman, "Women's Work," 609.

105 Sutton, "Soup and Supervision," 316-17.

106 On the decline of guild's control over the production of goods see: Wallis, "Controlling Commodities." According to Walker, subcontracting was considered only a minor infraction of guild's regulation because "it did not necessarily run counter to guild controls; the two [guild system and subcontracting] were not mutually exclusive, as the former was a form of industrial organisation, the latter a form of human association and Industrial control." Walker, "Extent of the Guild Control," 77.

107 As for instance cases of fraudulent behavior. Riello, "Shaping of a Family Trade."

108 See in particular Mitchell, "Coachbuilding." I thank the author for providing me with a copy of his paper. 
109 Cit. in Nockolds, Coachmakers, 59.

110 North, "Institutions," 187-88.

111 Styles, "Embezzlement," 173-74.

112 Old Bailey Proceedings, 6 July 1774: John Allies, John Mince, Theft, 469.

113 idem, 470.

\section{Bibliography of Works Cited}

\section{Books}

Wolken, T. A General Description of All Trades: Digested in Alphabetical

Order. London, 1747.

Ball, Michael, and Sunderland David. An Economic History of London, 1800-

1914. London: Routledge, 2001.

Barnett, David. London, Hub of the Industrial Revolution. A Review History, 1775-1825. London: Tauris Academic Studies, 1998.

Berg, Maxine, ed. Markets and Manufacture in Early Industrial Europe. London: Routledge, 1991.

Berg, Maxine, ed. The Age of Manufactures: Industry, Innovation and Work in Britain, 1700-1820, 2nd ed. London: Routledge, 1994.

Berg, Maxine. ed. Luxury and Pleasure in Eighteenth-Century Britain. Oxford:

Oxford University Press, 2005.

Berg, Maxine, Hudson Pat, and Sonenscher Michael, eds. Manufacture in

Town and Country Before the Factory. Cambridge: Cambridge University

Press, 1983.

Boyce, Gordon, and Ville Simon. The Development of Modern Business. Basingstoke:

Palgrave, 2002.

Campbell, R. The London Tradesman, Being a Compendious View of All the

Trades, Professions, Arts. London: T. Gardner, 1747.

Clifford, Helen. Silver in London: The Parker and Wakelin Partnership 1760-

1776. New Haven: Yale University Press, 2004.

Cox, Nancy. The Complete Tradesman. A Study of Retailing, 1550-1820.

Aldershot: Ashgate, 2000.

Defoe, Daniel. The Complete English Tradesman. . . London: Charles Rivington, 
1726.

DuPlessis, Robert S. Transitions to Capitalism in Early Modern Europe. Cambridge: Cambridge University Press, 1997.

Earle, Peter. The Making of the English Middle Class: Business, Society and Family life in London, 1660-1730. London: Methuen, 1989.

Edwards, Clive C. Eighteenth-Century Furniture. Manchester: Manchester University Press, 1998.

Fisher, Jack F. London and the English Economy, 1500-1700, eds. Penelope J. A3 Corfield and Negley B. Harte London: Hambledon Press, 1990.

Fox, Robert, and Anthony J. Turner, eds. Luxury Trades and Consumerism in Ancient R'egime Paris. Studies in the History of the Skilled Workforce. Aldershot: Ashgate, 1998.

Godley, Andrew. Jewish Immigrant Entrepreneurship in New York and London, 1850-1914. Basingstoke: Palgrave, 2001.

George, Dorothy. London Life in the Eighteenth Century. London: Kegan Paul, Trench, Tr * ubner, 1925.

Gilbert, Christopher. Life and Work of Thomas Chippendale. London: Studio Vista, 1978.

Green, David R. From Artisan to Paupers. Economic Change and Poverty in London, 1790-1870. Aldershot: Scolar Press, 1995.

Hall, Peter G. The Industries in London Since 1861. London: Hutchinson, 1962.

Hayward, Helena, and William Pat Kirkham, and Linnell John. Eighteenth Century London Furniture Makers. London: Studio Vista, 1980.

Kirkham, Pat. The London Furniture Trade 1700-1870. London: Furniture History Association, 1988.

La Roche, Sophie von. Sophie in London, 1786: Being the Diary of Sophie von La Roche. London: Cape, 1933.

Landes, David S. Revolution in Time: Clocks and the Making of the Modern World. Cambridge, Mass.: Harvard University Press, 1983.

Lemire, Beverly. Dress, Culture and Commerce. The English Clothing Trade Before the Factory, 1660-1800. Basingstoke: Routledge, 1997.

Linebaugh, Peter. The London Hanged. Crime and Civil Society in the Eighteenth 
Century. London: Allen Lane, 1991.

Morris, Corbyn. Observations on the Past Growth and Present State of the City of London. 1751. A4

Mortimer, Thomas. A General Commercial Dictionary Comprehending Trade, Manufactures and Navigation. London: Longman, 1819.

Nockolds, Harold. The Coachmakers. A History of the Worshipful Company

of Coachmakers and Coach Harness Makers. London: J. A. Allen, 1977.

Piore, Michael J., and Charles F. Sabel The Second Industrial Divide. New York: Basic Books, 1984.

Popp, Andrew. Business Structure, Business Culture, and the Industrial District: the Potteries, c. 1850-1914. Aldershot: Ashgate, 2001.

Porter, Michael. Cases in Competitive Strategies. London: Collier Macmillan, 1983.

Riello, Giorgio. A Foot in the Past: Consumers, Producers and Footwear in the Long Eighteenth Century. Oxford: Oxford University Press, 2006.

Rule, John. The Labouring Classes in Early Industrial England, 1750-1850.

London: Longman, 1986.

Sabel, Charles F., and Zeitlin Jonathan, eds. World of Possibilities: Flexibility and Mass Production in Western Industrialization. Cambridge: Cambridge University Press, 1997.

Schumacher, Ernst F. Small is Beautiful: A Study of Economics as if People Mattered. London: Harper and Row, 1973.

Schwarz, Leonard D. London in the Age of Industrialisation: Entrepreneurs, Labour Force and Living Conditions, 1700-1850. Cambridge: Cambridge University Press, 1992.

Scranton, Philip. Endless Novelty: Specialty Production and American Industrialization, 1865-1925. Princeton: Princeton University Press, 1997.

Sonenscher,Michael. The Hatters of Eighteenth-Century France. Berkeley and London: University of California Press, 1987.

Sonenscher, Michael. Work and Wages: Natural Law, Politics, and the Eighteenth-Century French Trades. Cambridge: Cambridge University Press, 1989. 
Snodin, Michael, and Styles John, Design and the Decorative Arts: Britain 1500-1800. London: Victoria and Albert Museum, 2001.

Stanziani, Alessandro, ed. La qualit'e des produits en France (XVIIIe-XXe Si`ecles). Paris: Belin, 2003.

Williamson, Oliver E. The Economic Institutions of Capitalism: Firms, Markets, Relational Contracting. New York: Free Press, 1985.

Wilson, John F., and Andrew Popp, eds. Industrial Clusters and Regional Business Networks in England, 1750-1970. Aldershot: Ashgate, 2003.

Zakim, Michael. Ready-Made Democracy. A History of Men’s Dress in the American Republic, 1760-1860. Chicago:University of Chicago Press, 2003.

\section{Articles and Essays}

Baker, Michael. "Roubiliac and Cheere in the 1730s and 40s: Collaboration and Sub-contracting in Eighteenth-century English Sculptors'Workshops.” Church Monuments 10 (1995): 90-108.

Berg, Maxine. "Small Producer Capitalism in Eighteenth-Century England." Business History 35 (Jan. 1993): 17-39.

Berg, Maxine. New Commodities, Luxuries and their Consumers in Eighteenth-Century England. In Consumers and Luxury: Consumer Culture in Europe, 1650-1850, eds. Maxine Berg and Helen Clifford. Manchester, 1999, pp. 63-85.

Berg, Maxine. "From Imitation to Invention: Creating Commodities in Eighteenth-Century Britain.” Economic History Review 55 (Feb. 2002): 130.

Berg, Maxine. "French Fancy and Cool Britannia: The Fashion Markets of Early Modern Europe.” Journal for the Study of British Culture 13 (Jan. 2006): 21-46.

Berg, Maxine, and Helen Clifford. Commerce and the Commodity: Graphic Display and Selling New Consumer Goods in Eighteenth-Century England. In Art Markets in Europe, 1400-1800, eds. North Michael and Ormrod David. Aldershot, 1998, pp. 187-200.

Berlin, Michael. 'Broken all in Pieces': Artisans and the Regulation of Workmanship in Early Modern London. In The Artisan and the European Town, 1500-1900, ed. Crossick Geoffrey. London, 1997, pp. 75-91. 
Bowett, Adam, and Laurie Lindey. "Labelled Furniture from the White Swan Workshop in St Paul's Churchyard (1711-35).” Furniture History IXL (2003): 71-98.

Casson, Mark, and Rose Mary B. Institutions and the Evolution of Modern Business: Introduction. In Institutions and the Evolution of Modern Business, eds. Casson Mark and Rose Mary B. London, 1998, pp. 1-25.

Chapman, Stanley D. "The Innovating Entrepreneurs in the British Readymade Clothing Industry.” Textile History 14 (June 1993): 5-25.

Chapman, Stanley D. “The 'Revolution’ in the Manufacture of Ready-made Clothing, 1840-1860.” London Journal 29 (2004): 44-61.

Subcontracting and the London Trades in Eighteenth Century 33

Church, Roy A. "New Perspectives on the History of Products, Firms, Marketing, and Consumers in Britain and the United States Since the MidNineteenth Century.” Economic History Review 52 (Aug. 1999): 405-35. Clifford, Helen. 'The King's Arms and Feathers'. A Case Study exploring the Networks of ManufactureOperating in the London Goldsmiths' Trade in the Eighteenth Century. In Goldsmiths, Silversmiths and Bankers. Innovation and the Transfer of Skill, 1550 to 1750, ed. Mitchell David. London, 1995, pp. 84-95.

Clifford, Helen. "Concepts of Invention, Identity and Imitation in the London and Provincial Metal-working Trades, 1750-1800.” Journal of Design History 12 (Aug. 1999): 241-56.

Clifford, Helen. "Innovation or Emulation? Silverware and its Imitations in Britain 1750-1800. The Consumers' Point of View.” History of Technology 23 (2001): 59-80.

Clifford, Helen. "A Nation of Shopkeepers: Trade Ephemera from 1655 to the 1860s in the John Johnson Collection.” Journal of Design History 15 (Aug. 2002): 275-80.

Clifford, Helen. Making Luxuries: The Image and Reality of Luxury Workshops in 18th-Century London. In The Vernacular Workshop: From Craft to Industry, 1400-1900, eds. P. A. Barnwell, Marilyn Palmer, and Malcolm Airs. York, 2004, pp. 17-27.

Coase, R. H. “The Nature of the Firm.” Economica 4 (1937): 386-405. 
Coquery, Natacha. "The Language of Success: Marketing and Distributing Semi-Luxury Goods in Eighteenth Century Paris.” Journal of Design History 17 (Jan. 2004): 71-89.

Cottereau, Alain. The Fate of CollectiveManufactures in the IndustrialWorld: the Silk Industries of Lyons and London, 1800-1850. In World of Possibilities: Flexibility and Mass Production in Western Industrialization, eds. Charles F. Sabel, and Jonathan Zeitlin. Cambridge, 1997, pp. 75152.

Cox, Nancy. 'Beggary of the Nation': Moral, Economic and Political Attitudes to the Retail Sector in the Early Modern Period. In A Nation of Shopkeepers: Five Centuries of British Retailing, eds. Benson John and Ugolini Laura. London, 2003, pp. 26-51.

Daunton, Martin J. “Industry in London: Revision and Reflections.” London Journal 16 (1996): 1-8.

Davies, Alun C. "British Watchmaking and the American System.” Business History 35 (Jan. 1993): 40-54.

de Munch, Bert. "La qualit'e du corporativisme. Strat'egies 'economiques et symboliques des corporations anversoises, XVIe-XVIIIe si ecles.” Revue d'Histoire Moderne et Contemporaine 54 (Jan. 2007): 116-44.

Decelauer, Harald. "Entrepreneurs in the Guilds: Ready To Wear Clothing and Subcontracting in Late 16th and Early 17th Century Antwerp." Textile History 31 (Nov. 2000): 133-49.

Deceulaer, Harald. "Between Medieval Continuities and Early Modern Change: Proto-industrialization and Consumption in the Southern Low Countries (1300-1800).” Textile History 37 (Nov. 2006): 123-48.

Farr, James R. "On the Shop Floor: Guilds, Artisans, and the European Market Economy, 1350-1750.” Journal of Early Modern History 1 (Feb. 1997): 2454.

Farr, James R. Cultural Analysis and Early Modern Artisans. In The Artisan and the European Town, 1500-1900, ed. Crossick Geoffrey. London, 1997, pp. 56-74.

Fox, Celina, "Images of Artists and Craftsmen in Georgian London.” Apollo 125 (1987): 357-63. 
A5 Ginsburg, Madeline. "The Tailoring and Dressmaking Trades, 1700-1850.” Costume 6 (1972).

Godley, Andrew. "The Development of the UK Clothing Industry, 1850-1950:

Output and Productivity Growth.” Business History 37 (Oct. 1995): 46-63.

Green, David R. “The Nineteenth-Century Metropolitan Economy.” London Journal 16 (1996): 10-23.

Gregory Clark. “Factory Discipline.” Journal of Economic History 54 (March 1994): 128-63.

Guerrini, Anna. "Anatomists and Entrepreneurs in Early Eighteenth-Century London.” Journal of the History of Medicine and Allied Sciences 59 (April 2004): 219-39.

Hall, Peter G. "The East London Footwear Industry. An Industrial Quarter in Decline.” East London Papers 5 (1965): 3-21.

Hatley, V. A. and Joseph Rajczonek. "Shoemakers in Northamptonshire 1762A6 1911: A Statistical Survey.” Northamptonshire Historical Series 6 (1971). Harvey, Charles, Edmund M. Green, and Penelope J. Corfield. "Continuity, Change, and Specialization Within Metropolitan London: the Economy of Westminster, 1750-1820.” Economic History Review 52 (Aug. 1999): 46993.

Hilaire-P'erez, Liliane. Les boutiques d'Inventeurs `a Londres et `a Paris au XVIIIe Si 'ecle: Jeux de l'Enchantement et de la Raison Citoyenne. In La Boutique et la Ville: Commerces, Commercants, Espaces et Clienteles, XVIe - XX si`ecle, ed. Natacha Coquery. Tours, 2000, pp. 203-21.

Hilaire-P'erez, Liliane, and Marie Th'ebaud-Sorger. "Les Techniques dans l'Espace Public. Publicit'e des Inventions et Litt'erature d'Usage au XVIIIe Si`ecle (France, Angleterre).” Revue de Synth`ese 127 (2006): 393-428. Hohenberg, Paul M. Urban Manufactures in the Proto-industrial Economy: Culture Versus Commerce? In Markets and Manufacture in Early Industrial Europe, ed. Berg Maxine. London, 1991, pp. 159-72.

Honeyman, Katrina, and Goodman Jordan. "Women’s Work, Gender Conflict, and Labour in Europe, 1500-1900.” Economic History Review 44 (Nov. 1991): 609-28.

Iliffe, Rob. "Material Doubts: Hooke, Artisan Culture and the Exchange of 
Information in 1670s London.” British Journal for the History of Science 28 (1995): 285-318.

Johnson, Paul. "Economic Development and Industrial Dynamism in Victorian London.” London Journal 16 (1996): 27-37.

Jones, S. R. H. “Technology and the Organization of Work: a Reply.” Journal of Economic Behaviour and Organization 4 (March 1983): 63-6.

Kaplan, Steven L. "The Luxury Guilds in Paris in the Eighteenth Century." Francia IX (1981): 257-95.

Kirkham, Pat. "Samuel Norman: A Study of an 18th Century Craftsman." Burlington Magazine 111 (1969), 501-13.

Kriegel, Lara. "Culture and the Copy: Calico, Capitalism, and Design Copyright in Early Victorian Britain.” Journal of British Studies 43 (April 2004): 23365.

Kusamitsu, Toshio. "British Industrialization and Design Before the Great Exhibition.” Textile History 12 (June 1981): 77-95.

Langlois, Richard N. "Chandler in a Larger Frame: Markets, Transaction Costs, and Organizational Form in History.” Enterprise \& Society 5 (Sept. 2004): $355-75$.

Lemire, Beverly. "Developing Consumerism and Ready-made Clothing in Britain 1750-1800.” Textile History 15 (June 1984): 21-44.

Lewis, Gillian. Producers, Suppliers, and Consumers: Reflections on the Luxury Trades in Paris, c.1500-c.1800. In Luxury Trades and Consumerism in Ancien R'egime Paris. Studies in the History of the Skilled Workforce, eds. Robert Fox and Anthony Turner. Aldershot, 1998, pp. 28798.

Michie, Ranald C. "London and the Process of Economic Growth since 1750." London Journal 17 (1997): 68-90.

McConnell, Anita. "From Craft Workshop to Big Business - The London Scientific Instrument Trade’s Responses to Increasing Demand, 1750-1820.” London Journal 19 (1994): 36-53. McKendrick, Neil. “Josiah Wedgwood and Factory Discipline.” Historical Journal 4 (March 1961): 30-55.

Morrison, A. D. The Role of Subcontractors in the Manufacture of Precision 
Instruments in Provincial England During the Industrial Revolution. In New Directions in Economic and Social History. Papers Presented at the 'New Researchers' Sessions of the Economic History Society Conference Held at Edinburgh. ed. Ian Blanchard. 1995, pp. 14-9.

Murray, Fergus. "The Decentralization of Production - The Decline of the Mass-Collective Worker?” Capitalist and Class 19 (1983): 74-99.

North, Douglass C. Institutions and a Transaction-Cost Theory of Exchange. In Perspectives on Positive Political Economy, eds. James E. Alt and Kenneth A. Shepsle Cambridge, 1990, pp. 182-94.

Pollard, Sidney. "Factory Discipline in the Industrial Revolution." Economic History Review 16 (June 1963): 254-71.

Porter, Michael. "From Competitive Advantage to Corporate Strategy.” Harvard Business Review 65 (1987): 43-59.

Reynard, Pierre C. "Manufacturing Strategies in the Eighteenth Century: Subcontracting for Growth among Papermakers in the Auvergne.” Journal of Economic History 58 (Feb. 1998): 155-82.

Reynard, Pierre C. "Manufacturing Quality in the Pre-industrial Age: Finding Value in Diversity.” Economic History Review 53 (Aug. 2000): 493-536. Riello, Giorgio. The Shaping of a Family Trade: the Cordwainers' Company in Eighteenth-Century London. In Guilds, Society and Economy in London, 1400-1800, eds. Gadd Ian A. and Wallis Patrick. London, 2002, pp. 141159.

Riello, Giorgio. “La Chaussure `a la Mode: Product Innovation and Marketing Strategies in Parisian and London Boot and Shoemaking in the Early Nineteenth Century.” Textile History 34 (Nov. 2003): 107-32.

Riello, Giorgio. "A Taste of Italy: Italian Businesses and the Culinary Delicacies of Georgian London.” London Journal 31 (2006): 201-22.

Richards, Eric. Margins of the Industrial Revolution. In The Industrial Revolution and British Society eds. Patrick K. O’Brien and Roland Quinault. Cambridge, 1993, pp. 203-28.

Sabel, Charles F., and Jonathan Zeitlin. "Historical Alternatives to Mass Production." Past \& Present 108 (Aug. 1985): 133-76.

Scott, Katie. “Archives and Collections. The Waddesdon Manor Trade Cards: 
More than One History.” Journal of Design History 17 (Jan. 2004): 91104.

Sharpe, Pam. “'Cheapness and Economy’: Manufacturing and Retailing ReadyMade Clothing in London and Essex 1830-50.” Textile History 26 (Nov. 1995): 203-13.

Smith, D. J. “Army Clothing Contractors and the Textile Industries in the 18th Century.” Textile History 14 (Nov. 1983): 153-64.

Smith, Roger. “The Swiss Connection: International Networks in Some Eighteenth-century Luxury Trades.” Journal of Design History 17 (May 2004): 123-40.

Spate, O. H. K. “Geographical Aspects of the Industrial Evolution of London Till 1850.” Geographical Journal 92 (1938): 422-32.

Styles, John. Embezzlement, Industry and the Law in England, 1500-1800. In Markets and Manufacture in Early Industrial Europe, ed. Maxine Berg, Pat Hudson, and Michael Sonenscher. Cambridge, 1983, pp. 173205.

Styles, John. Manufacturing, Consumption and Design in Eighteenth-Century England. In Consumption and the World of goods, eds. John Brewer and Roy Porter. New York and London, 1993, pp. 527-54.

Styles, John. The Goldsmiths and the London Trades, 1550-1750. In Goldsmiths, Silversmiths and Bankers: Innovation and the Transfer of Skills, 1550-1750, ed. David Mitchell. London, 1995, pp. 112-20.

Styles, John. "Product Innovation in Early Modern London.” Past \& Present 168 (Aug. 2000): 124-69.

Sutton, Paul. "Soup and Supervision: theMetropolitanWatch and Clock Making Trade 1797-1817.” Journal of Historical Sociology 9 (Sept. 1996): 315-

34.

Swann, June. "Mass Production of Shoes.” Journal of the International Association of Costume 14 (1997): 44-8.

Szostak, Rick. “The Organisation of Work: the Emergence of the Factory Revisited.” Journal of Economic Behaviour and Organisation 11 (May 1989):

343-58.

Thompson, E. P. “Time, Work-discipline, and Industrial Capitalism.” Past \& 
Present 38 (Dec. 1967): 56-97.

Trinder, Barry S. Industrialising Towns, 1700-1840. In The Cambridge Urban

History of Britain, Vol. 2: 1540-1840, ed. Clark Peter. Cambridge, 2000, pp. 805-30.

Wackernagekl, Rudolph H. "Carlton House Mews: the State Coach of the

Prince of Wales and of the Later King of Hanover. A study in the Late-

Eighteenth-century 'Mystery’ of Coach Building.” Furniture History 31 (1995): 47-115.

Wallis, Patrick. Controlling Commodities: Search and Reconciliation in the Early Modern Livery Companies. In Guilds, Society and Economy in London, 1400-1800, eds. Gadd Ian A. and Wallis Patrick. London, 2002, pp. 85-100.

Walsh, Clare. "Shop Design and the Display of Goods in Eighteenth-Century London.” Journal of Design History 8 (Sept. 1995): 157-76.

Williamson, Oliver E. "Transaction Cost Economics: The Governance of Contractual Problems.” Journal of Law and Economics 22 (Oct. 1979): 23361.

Williamson, Oliver E. "The Organization ofWork:AComparative Institutional Assessment.” Journal of Economic Behaviour and Organization 1 (March 1980): 5-38.

Williamson, Oliver E. "Technology and the Organization of Work: A Reply to Jones.” Journal of Economic Behaviour and Organization 4 (March 1983): 67-8.

Wrigley, E. A. “A Simple Example of London Importance in Changing English Society and Economy. 1650-1750.” Past \& Present 37 (1966): 44-68.

Young, Hilary. "Manufacturing Outside the Capital: the British Porcelain Factories, Their Sales Networks and Their Artists, 1745-1795.” Journal of Design History 12 (Aug. 1999): 257-69.

\section{Unpublished Works and Studies}

Federer, Andrew. "Payment, Credit and the Organization of Work in Eighteenth Century Westminster" Unpublished paper presented at the SSRC Conference on "Manufacture in Town and Country Before the Factory." Oxford, September 1980. 
Freundel, Werner J. "The Production and Commissioning of London-Made Private Carriages, 1740-1800.” Unpublished MA thesis, V\&A - RCA MA in History of Design, 1999.

Loftus, Donna, and Giorgio Riello. “'Historical Fashion': the Neglected Role of the London Economy.” Unpublished paper presented at the Association of Business Historian Conference, Churchill College, University of Cambridge, May 2003.

Mitchell, David. “Coachbuilding Case Study.” Unpublished Paper, 2004.

Sutton, Paul. "Metropolitan Artisans and the Discourse of the Trade, c. 17501825” Unpublished Ph.D. thesis, University of Essex, 1994.

Walker, M. J. "The Extent of the Guild Control of Trades in England, c. 16601820: a Study Based on a Sample of Provincial Towns and London Companies.” Unpublished Ph.D. thesis, University of Cambridge, 1986.

Wallis, Patrick. "Consumption, Retailing and Medicine in Early-Modern London.” Economic History Review forthcoming 2008 (earlyonline at Blackwells Website, 9 May 2007).

\section{Official Publications}

British Parliamentary Papers. Common’s Journal 23, (3 May 1738).

British Parliamentary Papers. Select Committee on Petitions Relating to Duty on Leather, 4 (no. 593, 1812-13).

\section{Archival Sources}

Old Bailey Proceedings, 6 July 1774: John Allies, John Mince, Theft, 469. 